\title{
Biometry of Arabian carpetshark, Chiloscyllium arabicumGubanov, 1980 (Elasmobranchii: Hemiscyllidae) from Iraqi marine water
}

\author{
Jassim M. Abed \\ Fisheries \& Marine Resources Dept., Agriculture Coll., Basrah Univ., Basrah Iraq \\ E. mail: akhbeel1@yahoo.com
}

\begin{abstract}
A total of 35 specimens (22 male and 13 female) of Arabian carpetshark Chiloscyllium arabicum Gubanov, 1980, ranging in total length from 262-731 mm were collected from Iraqi marine water (N: 29 46', E: 48 48') during December 2012 - April 2013 and April 2014.80 morphometrics and meristics were measured.The head length (HDL) was 17.0-19.2 mm and 16.9$19.7 \mathrm{~mm}$, and the interdorsal space (IDS) was12.3-19.9 $\mathrm{mm}$ and $11.7-22.1 \mathrm{~mm}$ for males and females respectively. Significant differences in some characters were found between males and females, the pelvic-anal space (PAS), the pelvic-caudal space (PCA) and the anterior vent-caudal tip length (VCL) in males were significantly larger than those in females, while the pre-pelvic fin length (PP2), the anal fin anterior margin length (ANA) and the pelvic base length (P2B) in females were significantly larger than those in males. The total count of vertebrae ranged between 162 and 175.
\end{abstract}

\section{Introduction}

Family Hemiscyllidae (Orectolobiformes) comprises small sharks, generally known as bamboo sharks, occurring in the tropical western Pacific and Indian Oceans (Cornish, 2005). There are two genera; Chiloscyllium with seven species and Hemiscyllium with five species. The maximum total length varies from 43 to $107 \mathrm{~cm}$ depending on species (Compagno, 2001).

Members of the Hemiscyllidae family are small, slender sharks with nasoral grooves, perinasal grooves, short barbels, small transverse mouths in front of eyes, dorsolateral eyes, large spiracles below eyes, no lateral skin flaps on head, two spineless dorsal fins, the second dorsal-fin origin well ahead of the anal-fin origin, a long low keel-like rounded anal fin separated from the lower caudal origin by a narrow notch, and a long precaudal tail much greater than the head and body length (Compagno, 2001).

However, the Arabian carpetshark Chiloscyllium arabicum is believed to occur in the western Indian Ocean (Compagno, 1984a), from the Arabian Gulf between Iraq and the Arabian Peninsula to the west coast of 
India (Weigmann, 2012; Froese \& Pauly, 2014).

Day (1878) recorded the genus Chiloscyllium from Indian waters under the family Scyllidae. Jordan (1923) assigned Chiloscyllium under the family Hemiscyllidae. But Fowler (1941) and Berg (1947) classified this genus under the family Orectolobidae. Compagno (1984a) dealt Chiloscyllium with the family Hemiscyllidae.

The Arabian carpetshark inhabits coral reefs, rocky shores, and mangrove estuaries. It is free-living at $10.1 \mathrm{~cm} \mathrm{TL}$, and feeds on squid, shelled molluscs, crustaceans, and snake eels (Compagno, 2001).

Presentstudy aims to enhance information on the taxonomy of the Arabian carpetsahrk through the morphometric and meristic features.

\section{Materials and Methods}

A total of 35 specimens (22 male and 13 female) of Arabian carpetshark Chiloscyllium arabicum Gubanov, 1980, 262-731 mm total length were collected from Iraqi marine water

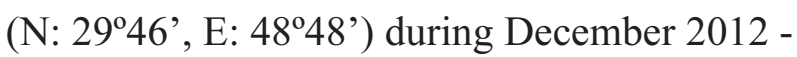
April 2013 and April 2014 . Fish specimens were caught by seine net.Head length and measurements of body parts are given as proportions of total length (TL).Morphometric and meristic dimensions were measured following (Compagno, 1984b) (fig.1). The common and scientific name followed Froese \& Pauly (2014). All specimens were deposited in the Department of Fisheries and marine resources, College of Agriculture, Basrah University. In the laboratory, different morphometric and meristic features were measured. The total and precaudal lengths of the specimens were determined to the nearest $\mathrm{mm}$ by a measuring board, and the lengths of the different dimensions were measured using electronic caliper and dissecting microscope. Ten specimens were used to calculate the total vertebrae after boiling in water and removing the skin and muscles.

\section{Results}

The distribution of the Arabian carpetshark, $C$. arabicum spreads in the Iraqi marine waters northwest of the Arabian Gulf and enters the Iraqi inland water in the Shatt Al-Arab River, (fig.1and 2) shows the different morphometric measurements.

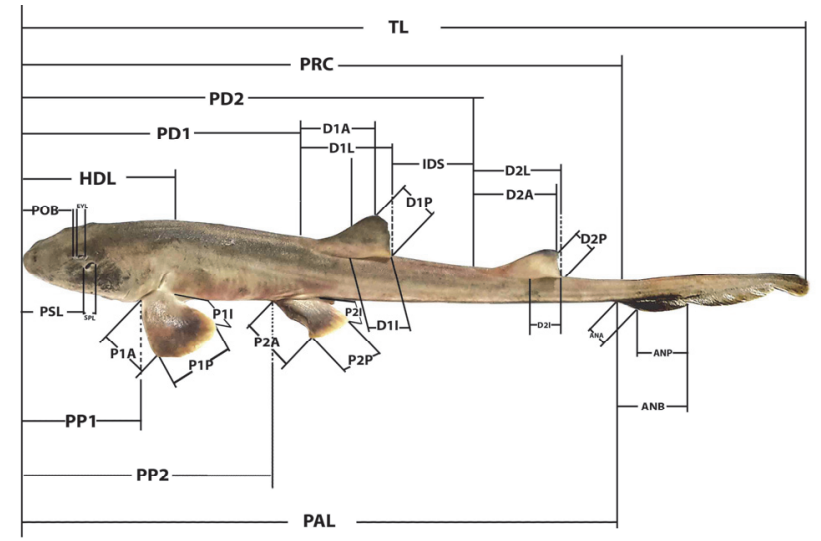

Figure (1). Arabian carpetshark, Chiloscyllium arabicum, 535 mm TL

The nostrils are subterminal on snout (Fig.2). Snout is rounded with small mouth with 
barbles well in front of eyes. The preoral snout is long, and the mouth is closer to eyes than snout tip. There is no black hood on head or large dark spot or spots on the sides of the body above the pectoral fins.

Table 1 shows the different measurements taken on males ranging from 304 to $731 \mathrm{~mm}$ TL and females ranging from 262 to $712 \mathrm{~mm}$ TL of $C$. arabicum. The head ilength (HDL) was17.0-19.2 $\mathrm{mm}$ and $16.9-19.7 \mathrm{~mm}$, the interdorsal space (IDS) was12.3-19.9 $\mathrm{mm}$ and 11.7-22.1, the pectoral base length (P1B) was 4.5-6.6 $\mathrm{mm}$ and 5.1-5.9 $\mathrm{mm}$, the dorsal fin 1 base length (D1B) was7.1-8.8mm, and 7.5$11.1 \mathrm{~mm}$, the dorsal fin 2 base length (D2B) was7.2-9.4 $\mathrm{mm}$ and7.3-12 $\mathrm{mm}$, The anal fin base length (ANB) was 8.1-12.1 $\mathrm{mm}$ and 8.6$12.2 \mathrm{~mm}$, the eye-spiracle length (ESL) was $0.7-1.6 \mathrm{~mm}$ and $0.56-1.5 \mathrm{~mm}$, the barble length (BL) was 1.0-2.6 mm and 1.7-2.5 mm, for males and females respectively. The SPSS analysis illustrated significant differences between males and females in some characters at $\mathrm{P}<0.01$ and $\mathrm{F}$ calculated were PAS (7.732), PCA (13.325) and VCL (8.555) for males, PP2 (6.378), ANA (6.305) and P2B (10.171) for females, total vertebrae were 162-175.

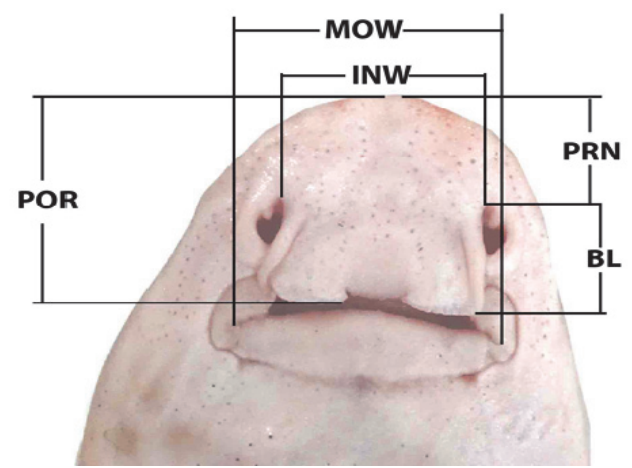

Figure (2).Underside of head of Chiloscyllium arabicum

\section{Discussion}

The body and tail were moderately cylindrical in shape, the snout fairly thick and rounded anteriorly and lateral ridges were absent from trunk. The dorsal fins were large and angular, somewhat larger than pelvic fins with projecting free rear tips, inter-dorsal space was very long, 12.3-19.9 and 11.7-22.1 mm., over twice as first dorsal base, 7.2-9.4 and 7.3-12 $\mathrm{mm}$. for male and female, respectively.

The first dorsal origin is located over or behind pelvic fin bases (fig.1), origin of anal fin somewhat lay behind the free rear tip of the first dorsal fin, anal fin length from origin to free rear tip is nearly less than hypural caudal lobe from the lower caudal origin to the free rear tip. This coincides well with the description of Compagno (2001).

In comparison with the results of Compagno (2001) and Dash et al.(2013), there was an acceptable consensus in the results of (pre pectoral fin length) PP1,( snout-anterior vent length) SVL, VCL, (eye length) EYL, D1B, (dorsal fin one vertical height) D1H,D2B and (dorsal fin two vertical height) D2H, (tab.2), while other measurements such as HDL, (pre Orbital length) POB, IDS, and (internarial width) INW were higher in the current study than those described previously by Dash et al. (2013). 
DOI : $10.4197 /$ Mar. 26-1.

Table(1) Different measurements of Chiloscyllium arabicum as proportions of total length

\begin{tabular}{|c|c|c|c|c|}
\hline \multirow{2}{*}{ Measurement } & \multicolumn{2}{|c|}{ male } & \multicolumn{2}{|c|}{ female } \\
\hline & Range & Mean $\pm \mathrm{Sd}$ & Range & Mean $\pm \mathrm{Sd}$ \\
\hline T.L. total length & $304-731$ & $456.48 \pm 131.89$ & $262-712$ & $394.23 \pm 117.1$ \\
\hline PRC pre caudal length & $73.2-82.8$ & $78.06 \pm 3.35$ & $57.4-82.7$ & $76.86 \pm 6.66$ \\
\hline PD1 preDorsal fin 1 length & $30.1-57.3$ & $41.09 \pm 10.64$ & $32.5-56.7$ & $42.36 \pm 11.14$ \\
\hline PD2 pre Dorsal fin 2 length & $32.7-63.2$ & $49.19 \pm 10.94$ & $34.0-58.6$ & $47.89 \pm 10.92$ \\
\hline HDL head length & $17.0-19.2$ & $17.98 \pm 0.59$ & $16.9-19.7$ & $18.18 \pm 0.86$ \\
\hline PSL pre spiracle length & $7.4-9.1$ & $8.15 \pm 0.46$ & $7.5-9.1$ & $8.25 \pm 0.47$ \\
\hline POB pre Orbital length & $6.1-7.6$ & $6.88 \pm 0.43$ & $6.3-9.6$ & $7.12 \pm 0.83$ \\
\hline PPl, pre pectoral fin length & $12.2-23.5$ & $14.96 \pm 2.31$ & $12.7-19.7$ & $15.48 \pm 1.68$ \\
\hline PP2, pre pelvic fin length & $29.1-34.1$ & $31.4 \pm 1.24$ & $30.0-35.1$ & $32.55 \pm 1.39$ \\
\hline SVL, snout-anterior vent length & $31.5-35.2$ & $33.63 \pm 0.85$ & $29.4-35.8$ & $33.54 \pm 2.05$ \\
\hline PAL, pre anal fin Length & $69.1-75.6$ & $71.6 \pm 1.65$ & $52.2-73.5$ & $69.73 \pm 5.42$ \\
\hline IDS, interdorsalspace & 12.3-19.9 & $14.13 \pm 1.8$ & $11.7-22.1$ & $13.90 \pm 2.66$ \\
\hline DCS, dorsal (D2)-caudal space & $18.0-27.3$ & $20.0 \pm 1.99$ & $18.0-20.5$ & $19.33 \pm 0.67$ \\
\hline PPS, pectoral-pelvic space & $11.5-19.9$ & $16.93 \pm 1.67$ & $15.7-19.2$ & $17.64 \pm 1.02$ \\
\hline PAS, pelvic-anal space & $38.1-44.8$ & $40.55 \pm 1.75$ & $37.0-41.2$ & $38.83 \pm 1.33$ \\
\hline ACS, anal-caudal space & $2.3-11.8$ & $9.57 \pm 2.89$ & $3.1-13.3$ & $8.89 \pm 3.86$ \\
\hline PCA, pelvic-caudal space & $49.1-57.7$ & $51.14 \pm 1.98$ & $37.8-52.2$ & $46.55 \pm 5.17$ \\
\hline VCL, anterior vent-caudal tip length & $57.7-68.4$ & $66.63 \pm 2.22$ & $46.3-66.9$ & $61.62 \pm 7.4$ \\
\hline PRN, prenarial length & $2.4-3.5$ & $2.88 \pm 0.27$ & $2.5-3.3$ & $2.86 \pm 0.22$ \\
\hline POR, preoral length & $3.4-4.8$ & $4.34 \pm 0.31$ & $3.4-5.0$ & $4.38 \pm 0.42$ \\
\hline EYL, eye length & $1.6-2.4$ & $2.05 \pm 0.21$ & $1.8-2.4$ & $2.13 \pm 0.19$ \\
\hline EYH, eye height & $0.6-1.3$ & $0.96 \pm 0.17$ & $0.7-1.8$ & $1.00 \pm 0.28$ \\
\hline ING, intrgill length $1^{\text {st }}$ to last slit & $4.61-5.84$ & $5.32 \pm 0,41$ & $4.44-543$ & $4.9 \pm 0.32$ \\
\hline GS1, 1st gill slit height & $1.4-2.0$ & $1.72 \pm 0.15$ & $1.0-1.9$ & $1.66 \pm 0.29$ \\
\hline GS2, 2nd gill slit height & $1.5-2.3$ & $1.97 \pm 0.19$ & $1.7-2.2$ & $1.99 \pm 0.17$ \\
\hline GS3, 3rd gill slit height & $1.7-2.8$ & $2.29 \pm 0.27$ & $1.9-2.5$ & $2.22 \pm 0.21$ \\
\hline GS4, 4th gill slit height & $1.8-2.6$ & $2.33 \pm 0.21$ & $1.9-2.4$ & $2.16 \pm 0.15$ \\
\hline
\end{tabular}




\begin{tabular}{|c|c|c|c|c|}
\hline GS5, 5th gill slit height & $2.1-3.2$ & $2.75 \pm 0.33$ & $2.2-2.8$ & $2.48 \pm 0.22$ \\
\hline $\mathrm{P} 1 \mathrm{~A}$, pectoral anterior margin 1. & $9.9-14.1$ & $12.73 \pm 1.16$ & $2.4-12.9$ & $10.50 \pm 3.72$ \\
\hline P1B, pectoral base length & $4.5-6.6$ & $5.68 \pm 0.64$ & $5.1-5.9$ & $5.42 \pm 0.36$ \\
\hline P1I, pectoral inner margin length & $4.7-6.8$ & $5.55 \pm 0.54$ & $4.6-6.3$ & $5.45 \pm 0.55$ \\
\hline $\mathrm{P} 1 \mathrm{P}$, pectoral posterior margin 1. & $6.3-9.9$ & $7.92 \pm 0.81$ & $5.3-9.7$ & $7.75 \pm 1.29$ \\
\hline $\mathrm{P} 1 \mathrm{H}$, pectoral height (base end to tip) & $9.0-11.8$ & $10.7 \pm 0.84$ & $6.9-11.8$ & $10.30 \pm 1.41$ \\
\hline P1L, pectoralleng. (ant.base to post tip) & $10.7-13.5$ & $12.04 \pm 0.98$ & $9.4-12.2$ & $11.23 \pm 0.99$ \\
\hline D1L, D1 total length & $10.1-13.0$ & $11.8 \pm 0.69$ & $10.8-12.4$ & $11.73 \pm 0.49$ \\
\hline D1A, D1 anterior margin length & $8.2-12.6$ & $11.15 \pm 1.0$ & $10.1-12.1$ & $11.26 \pm 0.68$ \\
\hline D1B, D1 base length & $7.1-8.8$ & $8.01 \pm 0.46$ & $7.5-11.1$ & $8.63 \pm 1.14$ \\
\hline D1H, D1 vertical height & $6.3-8.5$ & $7.54 \pm 0.57$ & $6.6-8.9$ & $7.87 \pm 0.7$ \\
\hline D11, D1 inner margin length & $2.7-3.4$ & $3.07 \pm 0.21$ & $2.8-3.5$ & $3.15 \pm 0.25$ \\
\hline D1P, D1 posterior margin length & $5.1-7.9$ & $6.75 \pm 0.79$ & $5.0-7.9$ & $6.24 \pm 0.83$ \\
\hline D2L, D2 total length & $9.9-11.3$ & $10.93 \pm 0.39$ & $9.8-11.2$ & $10.36 \pm 0.57$ \\
\hline D2A, D2 anterior margin length & $8.4-11.3$ & $9.76 \pm 2.13$ & $9.4-11.5$ & $10.50 \pm 0.72$ \\
\hline D2B, D2 base length & $7.2-9.4$ & $8.48 \pm 0.62$ & $7.3-12$ & $8.94 \pm 1.4$ \\
\hline D2H, D2 vertical height & $4.3-7.3$ & $5.95 \pm 0.74$ & $5.0-8.1$ & $6.17 \pm 0.87$ \\
\hline D2I, D2 inner margin length & $1.94-2.95$ & $2.43 \pm 0.30$ & $2.25-2.83$ & $2.50 \pm 0.18$ \\
\hline $\mathrm{D} 2 \mathrm{P}, \mathrm{D} 2$ posterior margin length & $4.1-6.5$ & $5.49 \pm 0.56$ & $2.7-6.2$ & $4.97 \pm 1.09$ \\
\hline P2L, Pelvic total length & $9.0-11.3$ & $10.42 \pm 0.62$ & $4.4-11.4$ & $9.24 \pm 2.09$ \\
\hline $\mathrm{P} 2 \mathrm{~A}$, pelvic anterior margin length & $7.8-10.2$ & $9.25 \pm 0.63$ & $7.8-10.5$ & $9.38 \pm 0.78$ \\
\hline $\mathrm{P} 2 \mathrm{~B}$, pelvic base length & $5.3-6.9$ & $6.02 \pm 0.51$ & $5.5-7.2$ & $6.43 \pm 0.59$ \\
\hline $\mathrm{P} 2 \mathrm{H}$, pelvic height (max. width) & $5.2-7.9$ & $6.93 \pm 0.67$ & $6.5-7.9$ & $7.2 \pm 0.59$ \\
\hline P2I, pelvic inner margin length & $2.9-5.9$ & $4.72 \pm 0.79$ & $3.5-7.0$ & $4.75 \pm 1.06$ \\
\hline $\mathrm{P} 2 \mathrm{P}$, pelvic posterior margin length & $5.0-7.3$ & $6.36 \pm 0.66$ & $4.0-7.3$ & $6.05 \pm 1.08$ \\
\hline ANL, anal fin total length & $8.8-13.3$ & $11.69 \pm 1.15$ & $6.1-13.5$ & $11.07 \pm 2.46$ \\
\hline ANA, anal fin anterior margin 1. & $4.2-7.3$ & $5.66 \pm 1.05$ & $4.4-13.3$ & $7.00 \pm 2.32$ \\
\hline ANB, anal fin base length & $8.1-12.1$ & $10.38 \pm 0.98$ & $8.6-12.2$ & $10.52 \pm 1.01$ \\
\hline $\mathrm{ANH}$, anal fin vertical height & $1.9-2.9$ & $2.50 \pm 0.30$ & $2.3-3.0$ & $2.65 \pm 0.23$ \\
\hline ANI, anal fin inner margin length & $1.0-2.2$ & $1.30 \pm 0.31$ & $0.9-3.2$ & $1.53 \pm 0.74$ \\
\hline
\end{tabular}




\begin{tabular}{|c|c|c|c|c|}
\hline ANP, anal fin posterior margin 1. & $5.3-8.0$ & $6.20 \pm 0.67$ & $5.8-7.5$ & $6.8 \pm 0.57$ \\
\hline $\mathrm{HDH}$, head height at $\mathrm{P}$ origin & $6.7-9.0$ & $7.81 \pm 0.63$ & $7.2-9.3$ & $8.08 \pm 0.76$ \\
\hline $\mathrm{ABH}$, abdomen height at $\mathrm{D} 1 \mathrm{~B}$ end & $4.5-6.6$ & $5.81 \pm 0.66$ & $5.2-7.5$ & $6.09 \pm 0.7$ \\
\hline TAH, tail height at pelvic base end & $4.9-7.3$ & $6.16 \pm 0.62$ & $4.7-7.2$ & $6.24 \pm 0.73$ \\
\hline $\mathrm{CPH}$, caudal peduncal height & $2.8-3.4$ & $3.16 \pm 0.19$ & $2.9-3.5$ & $3.23 \pm 0.17$ \\
\hline $\mathrm{CPW}$, caud. p. width at caud. orign & $1.0-1.7$ & $1.30 \pm 0.20$ & $1.2-1.5$ & $1.38 \pm 0.11$ \\
\hline MOL, mouth length (arc radius) & $2.7-3.7$ & $3.44 \pm 0.27$ & $1.9-3.6$ & $3.13 \pm 0.39$ \\
\hline MOW, mouth width & 3.9-5.8 & $4.52 \pm 0.46$ & $3.4-5.1$ & $4.19 \pm 0.854$ \\
\hline SPL, spiracle length & $1.1-1.6$ & $1.32 \pm 0.14$ & $1.2-1.6$ & $1.35 \pm 0.18$ \\
\hline INW, internarial width & $3.1-4.0$ & $3.57 \pm 0.23$ & $3.2-4.2$ & $3.63 \pm 0.28$ \\
\hline ESL, eye-spiracle length & $0.7-1.6$ & $1.11 \pm 0.23$ & $0.56-1.5$ & $1.11 \pm 0.22$ \\
\hline HDW, head width at middl gill slits & $9.4-11.5$ & $10.45 \pm 0.67$ & $10.7-11.5$ & $11.01 \pm 0.42$ \\
\hline TRW, trunk width at $\mathrm{P}$ base ends & $9.3-13.5$ & $11.08 \pm 0.99$ & $9.9-13.7$ & $11.35 \pm 1.17$ \\
\hline $\mathrm{ABW}$, abdomen width at $\mathrm{D} 1 \mathrm{~B}$ end & $4.0-6.2$ & $5.54 \pm 0.63$ & $5.2-6.2$ & $5.59 \pm 0.39$ \\
\hline TAW, tail width at pelvic base end & 4.8-6.9 & $6.09 \pm 0.51$ & $5.0-8.9$ & $6.23 \pm 0.99$ \\
\hline CLI, clasper inner margin length & $0.95-12.5$ & $4.61 \pm 2.850$ & - & - \\
\hline CLO, clasper outer margin length & $0.64-6.3$ & $1.94 \pm 1.88$ & - & - \\
\hline CLB, clasper base width & $0.5-2.6$ & $1.16 \pm 0.59$ & - & - \\
\hline BL. barble length & $1.0-2.6$ & $2.07 \pm 0.4$ & $1.7-2.5$ & $2.15 \pm 0.25$ \\
\hline INO, interorbital space & $4.1-5.0$ & $4.94 \pm 0.34$ & $4.3-4.9$ & $4.56 \pm 0.23$ \\
\hline PD1R, pre dorsal 1ridge length & $2.11-2.34$ & $2.19 \pm 1.01$ & $2.07-2.22$ & $2.14 \pm 0.66$ \\
\hline IDR, iner dorsal ridge space & $10.9-12.0$ & $11.60 \pm 0.43$ & $9.9-14.4$ & $11.98 \pm 1.84$ \\
\hline Total vertebrae & \multicolumn{4}{|c|}{$162-175(169.1 \pm 4.14)$} \\
\hline
\end{tabular}


From the data of the current study, this species could be differentiated from $C$. griseum by inter-dorsal space which was about twice as long as $1^{\text {st }}$ dorsal fin base, while in $C$. griseum it do not exceed 1.5 times as long as $1^{\text {st }}$ dorsal fin base. Dorsal fins are also larger than pelvic fins in C. griseum, although they were smaller than those mentioned previously by Carpenter et al. (1997). In addition, the dorsal ridges of $C$. griseumare are not prominent or even absent as shown by Compagno (2001). Moreover, all of the examined specimens have distinct pre- and inter-dorsal ridges.

The collected specimens in the present study do not have faded stripes on their caudal fin and the base of the second dorsal fin is longer than that of the first dorsal fin. The rudimentary alternate dark and light bands which showed in C. griseum do not appear in C. arabicum. Additionally, C. griseum distribution area ranges from Pakistan and India over most parts of Southeast Asia to Papua New Guinea in the south and East China and South Japan in the north as demonstrated by Compagno (2001).

Mahdi (1971) and Al-Daham

mentioned the presence of $C$. griseum in the Iraqi marine waters. Hussain et al. (1988) also recorded the two species from Khor Al-Zubair, North West of the Arabian Gulf. However, the previous studies that indicated the presence of C. griseum in the Iraqi marine waters did not supported with thorough taxonomic information, although Carpenter et al. (1997) pointed to the presence of the $C$. arabicum in the Arabian Gulf. More recently, Jabado and Ebert (2015) mentioned the occurrence of $C$. arabicum in the Arabian Gulf and the Gulf of Oman in contrast to $C$. griseum which occur only in the southern part of the Arabian Gulf and Gulf of Oman.

The current study is consistent with the above researchers about the presence and the spread of Arabian carpetshark Chiloscyllium arabicum in the Iraqi marine waters North West Arabian Gulf.

Table (2 ) Comparison for some measurement with previous studies

\begin{tabular}{|c|c|c|c|}
\hline Measurement & $\begin{array}{c}\text { Compagno, } \\
2001\end{array}$ & $\begin{array}{c}\text { Dash } \text { et } \\
\text { al., } 2013\end{array}$ & Present study \\
\hline HDL & - & 8.57 & $16.9-19.7$ \\
\hline POB & - & 3.62 & $6.1-9.6$ \\
\hline PP1 & $16.1-19.6$ & - & $12.2-23.5$ \\
\hline SVL & $33.1-36.3$ & 28.57 & $29.4-35.8$ \\
\hline IDS & $8.7-14.5$ & 10.48 & $11.2-22.1$ \\
\hline VCL & $61.0-67.6$ & 60.0 & $46.4-68.3$ \\
\hline EYL & $1.4-1.8$ & 1.14 & $1.6-2.4$ \\
\hline D1B & - & 5.7 & $7.1-11.1$ \\
\hline D1H & $4.5-8.4$ & 7.62 & $7.3-8.9$ \\
\hline D2B & - & 6.29 & $7.2-12.0$ \\
\hline D2H & $4.2-7.1$ & 6.86 & $4.3-8.1$ \\
\hline MOL & - & 4.76 & $1.9-3.7$ \\
\hline INW & - & 2.86 & $3.1-4.2$ \\
\hline TL mm & - & 525 & $262-712$ \\
\hline & & & \\
\hline
\end{tabular}




\section{References}

Al-Daham, N. K. (1977) Fish of Iraq and the Arab Gulf. Center Arab Gulf Studies Publications(9). Al- Irshad Press, Baghdad, Vol. (1). 546pp.(In Arabic).

Berg, L. S.(1947) Classification of fishes, both recent and fossil (Trans.). Univ. Michigan, MiMgan. 380pp.

Carpenter, K. E.; krupp, F.; Jones, D.A. and Zajonz, U. (1997). FAO species identification guide for fishery purposes. The living marine resources of Kuwait, Eastern Saudi Arabia, Bahrain, Qatar and the United Arab Emirates. Rome, FAO. 293pp, 17 color plates.

Compagno, L. J. V.(1984a) Interrelationships of livingelasmobranchs. In: P. H. Greenwood et al. (Ed.) Interrelationships of fishes. Academic press, London; $\mathrm{p}$. 15-61.

Compagno, L.J.V. (1984b) FAO Species Catalogue, Vol. 4, Sharks of the world. An annotated and illustrated catalogue of sharks known to date. Part 1. Hexanchiformes to Lamniformes, FAO Fisheries Synopsis No. 125 vol.4 part 1, 1-249.

Compagno, L.J.V. (2001) Sharks of the world. An annotated and illustrated catalogue of shark species known to date. Bullhead, mackerel and carpet sharks (Heterodontiformes, Lamniformes and Orectolobiformes). FAO Species Catalogue for Fishery Purposes. 2(1) Rome, FAO. 269pp.

Cornish A. S. (2005) First observation of mating in the bamboo shark Hemiscylliumfreycineti (Chondrichthyes: Hemiscylliidae). Zoological Studies 44(4): 454-457.

Dash, S. S. ; Sangeetha, B ; Kamalia K. R. and Zala, M. S. (2013) Egg case of Arabian carpetshark,
Chiloscyllium arabicum from Gujarat. Mar. Fish. Inform. Serv.Tech. \& Exten. Ser., No. 218. 14-15.

Day, F. (1878) (Reprinted 1958) The fishes of India. William Dawsons\& Sons, London.(cited by Devadoss, 1986)

Devadoss, P. (1986) Studies on the catshark Chiloscyllium griseum from Indian waters. J. mar. biol. Ass. India, 28 (1 \& 2): 192 - 198

Fowler, H. W. (1941) Contribution to the biology of the Philippine Archipelago and adjacent regions. Bull. U. S. natn. Mus., (100) 13: 1-879.

Froese, R. and D. Pauly. Editors. (2014) FishBase. World Wide Web electronic publication. www. fishbase.org, version (04/2014). 3/5/2014

Gubanov, E. P. (1980) Chiloscyllium arabicum n. Sp. pp: 1417. In Gubanov, E. P. and Shleib, N. A. (Eds.). Sharks of the Arabian Gulf. Ministry of Public Works. Kuwait. $69 \mathrm{pp}$.

Jabado, R.W. and Ebert, D.A. (2015) Sharks of the Arabian Seas: an identification guide. The International Fund for Animal Welfare, Dubai, UAE.240 pp.

Jordan, D . S. (1923) A classification of fishes including families and genera as far as known. Standford Univ. Publication Biolog. Sci., 3: 80-243.

Hussain, N.A.; Naiama, A.K. and Al-Hassan, L.A.J. (1988) Annotated check list of the fish fauna of Khor Al-zubair, Norh West of the Arabian Gulf, Iraq. ActaIchthyo. et Piscatoria, 18: 17-24.

Mahdi, N. (1971) Additional to the marine fish fauna of Iraq. Iraqi Nat. Hist. Mus., publ. No.23. 43pp+16 plates.

Weigmann, S. (2012) Contribution to the taxonomy and distribution of six shark species (Chondrichthyes, Elasmobranchii) from the Gulf of Thailand. International Scholarly Research Network, ISRN Zoology, : 1-24. 


\section{Chiloscyllium الصفات المظهرية والعددية لقرش الخيزران العربي arabicumGubanov, 1980 المياه البحريـة العراقية \\ جاسم محسن عبد \\ قسم الأسماك والثروة البحرية،كلية الزراعة، جامعة البصرة، البصرة، العراق \\ البريد الأكتروني: akhbeel1@yahoo.com}

Chiloscyllium المستخلص. جمع 0ب فرد (r ذكر و با أنثى) من قرش الخيزران العربي arabicum Gubanov, 1980 العراقية من المنطقة ذات الأحداثيات 'N: 2946’, E: 4848 خلال الفترة من كانون الثاني

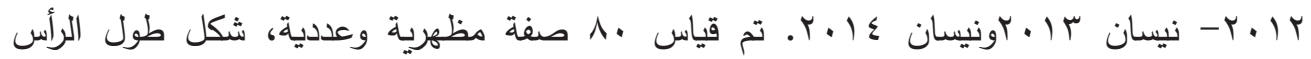
19, Y-IV, •

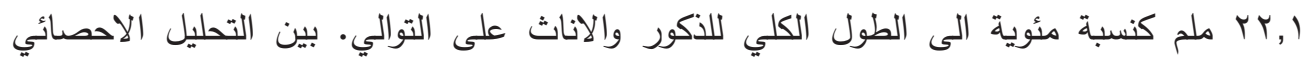
فروقات معنوية بين الذكور والاناث في بعض الصفات مثل المسافة بين الزعنفة الحوضية-الزعنفة المخرجية والمسافة بين الزعنفة الحوضية-الزعنفة الذنبية والطول من مقدمة المخرج-قية الزية الزعنفة الذنبية لصالح الذكور، بينما المسافة قبل الزعنفة الحوضية وطول الحافة الأمامية للزعنفة المخرجية

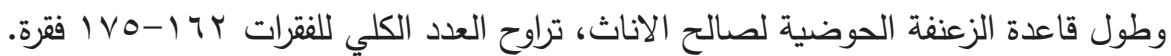

